\title{
COMPARISON OF FULL-TIME AND DISTANCE LEARNING PROGRAMMING
}

\author{
Rostislav FOJTÍK*, Ostravská univerzita v Ostravě
}

Přijato: 16. 2. 2015 / Akceptováno: 25. 5. 2015

Typ článku: Výzkum

DOI: $10.5507 /$ jtie.2015.002

Abstract: The aim of this paper is to show the differences between teaching programming in the form of full-time and distance learning. The author shows the basic problems, difficulties and practical experience with these forms and its specifics in teaching of programming. E-learning in the education system brings many advantages over traditional forms. This form of education also brings many difficulties that lead to less successful students while studying. The author presents the main criteria for improving the quality of distance learning programming and practical experience of teaching at the University of Ostrava. The author demonstrates specific ways of solving problems that brings e-learning in an accredited study

Key words: Distance education, Learning Management System, Moodle, didactic test, tutor.

\section{SROVNÁNÍ PREZENČNÍ A DISTANČNÍ VÝUKY PROGRAMOVÁNí}

Resumé: Cílem přispěvku je představit rozdíly mezi výukou programování $v$ prezenční a distančni formě výuky. Autor ukazuje základní problematiku, obtiže a praktické zkušenosti s těmito formami a jejich specifika při výuce programování. E-learning přináši v systému vzděláváni mnohé výhody oproti tradičním formám. Na druhé straně tato forma obsahuje i nové obtiže, které vedou např́klad $k$ menši úspěšnosti studenti̊ při studiu. Autor uvádi hlavni kritéria pro zvyšováni kvality distančni výuky programování a praktické zkušenosti s výukou na Ostravské univerzitě. Na praktických ukázkách představuje konkrétni způsoby řešeni problémů, které e-learning přináši $v$ akreditovaném studiu.

Klíčová slova: Distanční výuka, Learning Management System, Moodle, didaktické testy, tutor.

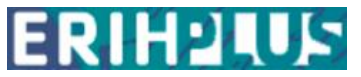

*Autor pro korespondenci: fojtik@osu.cz
This journal was approved on 2015-04-23 according to ERIH PLUS criteria for inclusion. 


\section{1 Úvod}

Moderní informační a komunikační technologie umožňují zkvalitnění distanční a kombinované formy výuky. V současnosti jsou obě tyto formy vzdělávání velmi žádány. Důvodem jsou neustále dynamicky rozvíjející se požadavky na znalosti a dovednosti pracovníků v různých profesích. Obzvláště to platí v oblasti informatiky. Distanční a kombinovaná forma výuky by měla studentům přinášet stejnou kvalitu jako forma prezenční. Proto je potřeba zajistit evaluaci a srovnání všech forem výuky. [2]

Katedra informatiky a počítačů na Ostravské univerzitě v Ostravě se distančním a kombinovaným studiem vakreditovaných programech zabývá již od roku 1998, a to v bakalářských oborech Aplikovaná informatika, Informační systémy i v navazujícím magisterském oboru Informační systémy. Distanční a kombinovaná forma studia nabízí možnosti studia studentům, kteří vzhledem k osobním a pracovním důvodům nemohou studovat stejné studijní obory prezenčně. Přes nesporné výhody distanční formy výuky, přináší tato forma nové obtíže a problémy.

Distanční a kombinovaná forma studia se na katedře liší jen počtem prezenčních tutoriálů. $\mathrm{V}$ distanční formě má semestrální kurz obvykle tři prezenční tutoriály v délce 2 až 3 vyučovacích hodin. V kombinované formě je počet tutoriálů obvykle 5 až 6 . Vzhledem k podobnosti mezi distanční a kombinovanou formou výuky jsou v článku všechny údaje a výsledky obou forem studia uváděny společně.

\section{Výuka programování}

Nedílnou součásti informatického vzdělání je oblast programování. Absolventi studia musí získat nejen potřebnou dávku teoretických znalostí, ale rovněž velmi mnoho praktických dovedností a zkušeností. Teprve pak mohou správně pochopit principy programování a následně vytvářet kvalitní programy. Proto jsou předměty zabývající se výukou programování rozděleny na teoretickou část (obvykle přednášky) a část praktickou (semináŕe), kde se studenti pod dohledem vyučujícího prakticky seznamují s tvorbou programů, psaním kódů, jednotlivými komponentami programovacího jazyka, vytvářením projektů a podobně. Tyto praktické dovednosti je potřeba správným způsobem předat $\mathrm{i}$ studentům $\mathrm{v}$ distančním a kombinovaném studiu. Je však potřeba zvolit jiné metodické př́stupy, ale zachovat stejnou kvalitu studia. Proto je vhodné prezenční a distanční formu studia porovnat. [4] [5]

\section{Srovnání úspěšnosti jednotlivých forem studia}

Jednou z možností porovnání kvality prezenčního, kombinovaného a distančního studia je srovnání míry úspěšnosti dokončení jednotlivých výukových kurzů. Pro srovnání byly využity statistiky úspěšnosti ve vybraných kurzech bakalářského studia informatiky, a to v několika akademických letech v prezenční a distanční formě studia. Požadavky na studenty obou forem jsou naprosto shodné, protože z hlediska obsahového se jedná o stejné studijní programy, které se liší pouze formou studia. Vyučující při hodnocení nerozlišují studenty prezenční od distančních. Zkoušky a udělování zápočtu často probíhá pro studenty oboru forem studia ve stejných termínech. $Z$ těchto důvodů je možné výsledky úspěšnosti vzájemně porovnávat. Přes skutečnost, že studenti distanční formy mají veškeré studijní materiály připraveny v elektronické podobě, jsou jejich výsledky v první části studia výrazně horší než u prezenčních studentů. [3]

První graf ukazuje srovnání úspěšnosti studentů prezenční a distanční formy ve vybraných kurzech bakalářského studia informatiky. Kurzy jsou v grafu 
a následujícím popisu očíslovány. Kurzy prvního semestru: 1. Základy programování, 2. Architektura počítačů, 3. Základy operačních systémů. Kurzy druhého semestru: 4. Algoritmy a datové struktury, 5. Operační systémy 1. Kurzy třetího semestru: 6. Základy umělé inteligence 1, 7. Základy databází. Kurzy čtvrtého semestru: 8. Počítačové sítě 1,9 . Relační databáze. Kurzy pátého semestru: 10. Počítačové sítě 2 , 11. Programování v C, 12. Základy statistiky. Kurzy šestého semestru: 13. Analýza dat, 14. Programování v $\mathrm{C}++$. Černé sloupce představují procenta úspěšných studentů v prezenční formě studia, šedé sloupce pak procenta úspěšných studentů distanční formy.

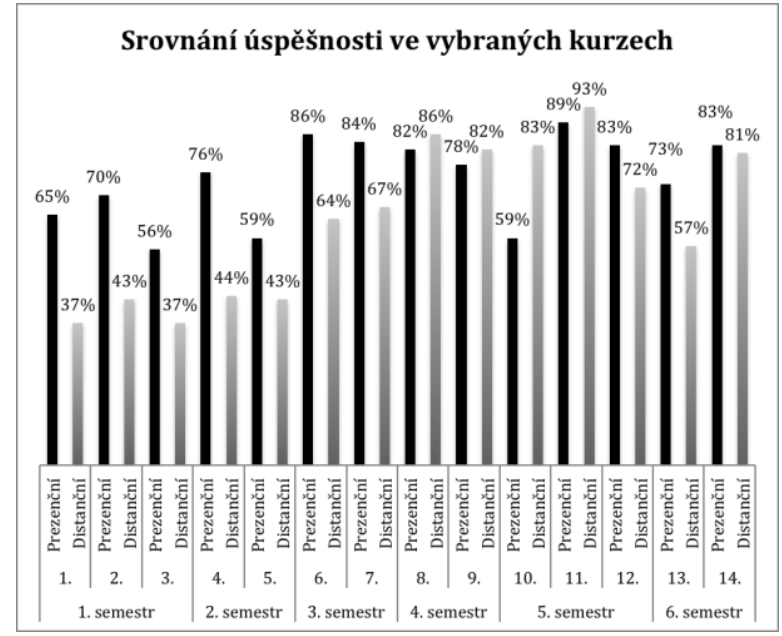

Obr 1: Srovnání úspěšnosti studentů v kurzech

Srovnáme-li úspěšnost studentů $\mathrm{v}$ jednotlivých ročnících bakalářského studia, zjistíme, že v prvním ročníku je rozdíl mezi studenty prezenčního a distančního studia největší. Zatímco úspěšných studentů ve vybraných kurzech prezenční formy bylo $66 \%$, pak u distančních studentů pouhých $41 \%$. V druhé ročníku byli prezenční studenti úspěšnější již jen o $8 \%$. V závěrečném ročníku bakalářského studia informatiky byl rozdíl pouhá dvě procenta ve prospěch prezenčních studentů.

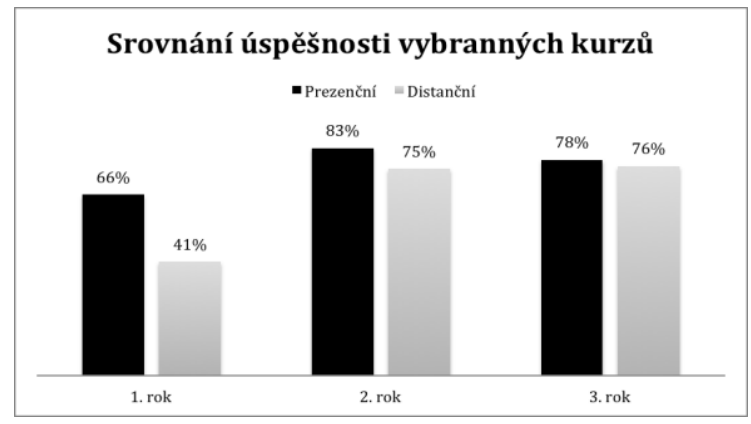

Obr 2: Srovnání úspěšnosti studentů v ročnicich 
Naprosto nejmenší úspěšnost měli studenti distančního studia v prvním semestru. Jednalo se o pouhých $39 \%$. V tomto období také nejvíce studentů distanční formy studium ukončí.

Příčinou špatných výsledků hlavně v prvním ročníku je skutečnost, že nemalá část studentů $\mathrm{v}$ distanční nebo kombinované formě studia nemá zkušenosti s těmito formami výuky, neumí plánovat, průběžně a pravidelně studovat, chybí ji možnost častější komunikace se spolužáky a tutorem. $\mathrm{V}$ druhé polovině prvního semestru pak tito studenti zjišt'ují, že neodevzdali požadované korespondenční úkoly včas a studium ukončují. Z analýzy vybraných předmětů prvního semestru vyplývá, že až 38 \% studentů distanční a kombinované formy se vůbec nedostavilo ke zkoušce.

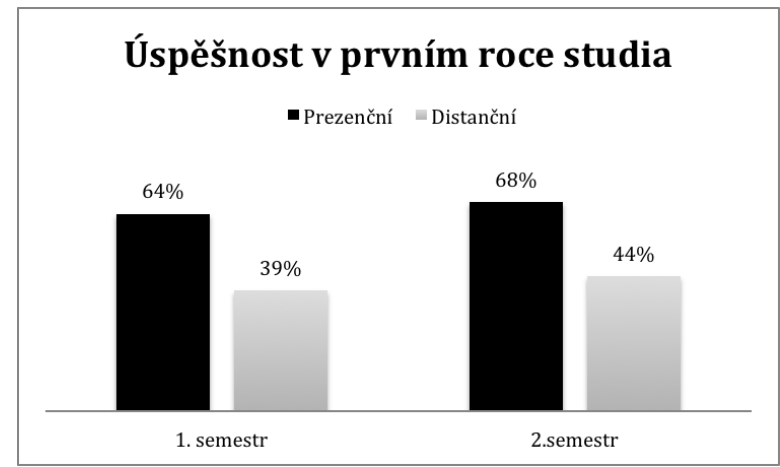

Obr 3: Srovnání úspěšnosti studentů v prvním semestru

Následující grafy porovnávají úspěšnost $\mathrm{v}$ některých předmětech zaměřující se na programování. První graf ukazuje srovnání úspěšnosti prezenčních a distančních studentů $\mathrm{v}$ předmětu Základy programování, který je obvykle vyučován v prvním semestru prvního ročníku. Výsledky jasně ukazují, že distanční studenti dosahují mnohem menší procento úspěšného dokončení předmětu. Zatímco úspěšných prezenčních studentů je průměrně $69 \%$, pak u distančních studentů je to pouze $42 \%$.

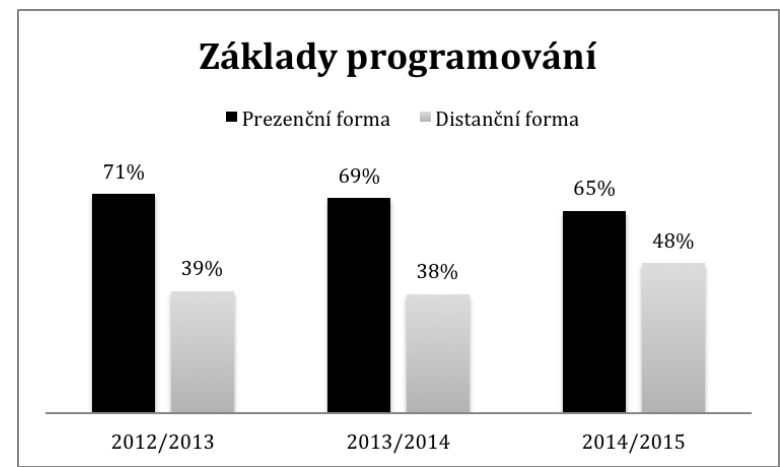

Obr 4: Srovnáni úspěšnosti studentů v předmětu Základy programování 
Předmět Objektově orientované programování si studenti obvykle zapisují ve třetím semestru bakalářského studia. Rozdíl mezi prezenčními a distančními studenty již není tak výrazný. Úspěšných studentů prezenčního studia bylo průměrně $74 \%$, úspěšných distančních studentů bylo $62 \%$.

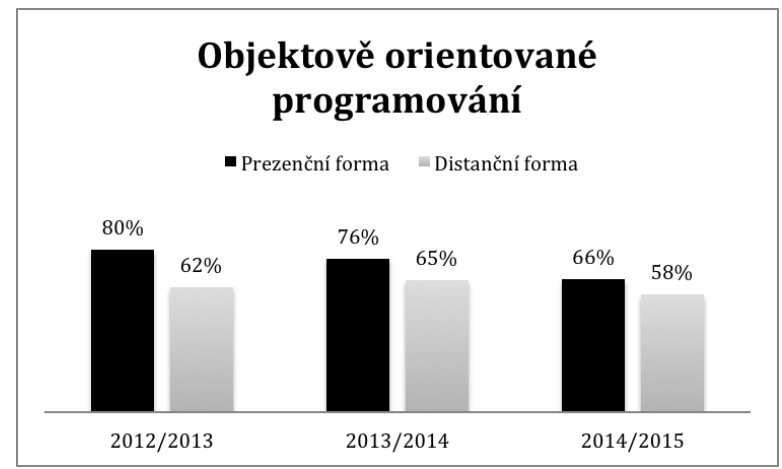

Obr 5: Srovnání úspěšnosti studentů v předmětu Objektově orientované programování

Poslední dva grafy ukazují srovnání úspěšného ukončení v předmětech vyučovaných v pátém a šestém semestru bakalářského studia.

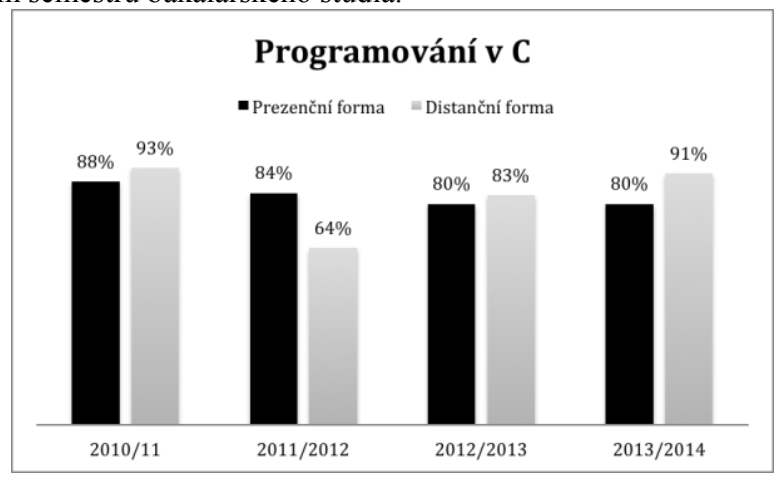

Obr 6: Srovnáni úspěšnosti studentů v předmětu Programování v C

$\mathrm{V}$ předmětu Programování $\mathrm{v} \mathrm{C}$ je průměrná úspěšnost distančních a prezenčních studentů téměř stejná. 


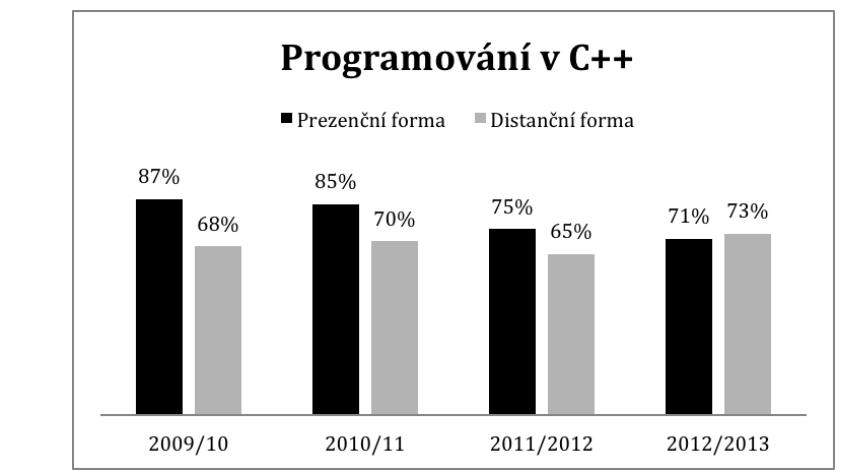

Obr 7: Srovnání úspěšnosti studentů v předmětu Programování v C++

Důležitou roli pro úspěšné ukončení studijního kurzu je aktivita a průběžná práce studentů během celého semestru. Z praktických zkušeností se ukazuje, že pro distanční výuku je potřeba zajistit, aby studenti pracovali rovnoměrně během celého semestru. To lze např́iklad zajistit pomocí termínování korespondenčních úkolů. Termíny je potřeba pravidelně rozdělit na celou dobu trvání semestru. Na prŕkladu předmětů Programování v C a Programování v C++ je vidět rozdíl ve výsledcích úspěšnosti. Ta byla lepší u prvního z předmětů. Mimo jiné $\mathrm{k}$ tomu přispěla skutečnost, že v prvním kurzu měli studenti kromě tří základních korespondenčních úkolů možnost získat body za šest dobrovolných doplňkových úkolů. Termíny odevzdání všech úkolů byly určeny průběžně během celého semestru. Téměř každý týden mohl student odevzdat některý z vytvořených programů. Sledováním aktivit studentů v LMS Moodle se potvrdilo, že četnost př́stupů do LMS, komunikace v elektronické konferenci a odevzdávání úkolů byla mnohem větší než v kurzu Programování v C++. V tomto kurzu byl použit model odevzdání jen jednoho menšího průběžného úkolu a jednoho většího samostatného projektu.

\section{Možnosti zvýšení kvality distanční formy výuky programování}

Ze zkušeností vyplývá, že pro zvýšení kvality distanční výuky programování je vhodné zajistit následující prvky online kurzů:

- studijní materiál v elektronické podobě,

- aktivní elektronická konference,

- animace a video návody,

- video přednášky,

- řešené praktické prŕíklady a projekty,

- elektronické didaktické testy,

- správa korespondenčních úkolů,

- $\quad$ správa aktivit studentů.

Prvním prvkem e-learningového kurzu je učební materiál velektronické podobě, který svými náležitostmi odpovídá požadavkům distančního učebního textu. [1]

Jedním $\mathrm{z}$ důležitých prvků $\mathrm{v}$ distanční výuce se jeví elektronická konference, která hraje nezastupitelnou roli v komunikaci mezi účastníky kurzu. Na rozdíl od zasílání 
e-mailů vidí aktivitu v konferenci všichni účastníci. Z hlediska zlepšení kvality distanční výuky programování se ukázala důležitá možnost získat část bodů potřebných pro udělení zápočtu právě za aktivitu v elektronické konferenci kurzu. Zavedením této možnosti se výrazně zvýšila aktivita studentů. Využivání e-mailů se obvykle omezovalo jen na období kolem odevzdávání korespondenčních úkolů a psaní odpovědí značně zatěžovalo tutora kurzu, který musel často odpovídat na podobné otázky. Zavedením elektronické konference a jejího bodování je aktivita účastníků kurzu častější a rovnoměrně rozdělená během celého semestru. Studenti často sami odpovídají na otázky svých spolužáků a tutor nemusel př́liš zasahovat do komunikace.

Častým problémem některých studentů je správná konfigurace vývojových nástrojů a práce s nimi. Prezenční studenti mohou potřebné informace a dovednosti získat na praktických cvičeních. Pro studenty distančního studia je však potřeba připravit takové materiály, aby jim při práci co nejvíce pomohly. Většinou nestačí obyčejný text doplněný obrázky. Některé úkony při práci s vývojovými nástroji jsou složité a vyžadují hlubší vysvětlení. Jako vhodné se ukázaly video návody, ve kterých je zobrazen a př́padně vysvětlen praktický postup.

Jako další vhodným nástrojem pro e-learningový kurz se ukazují video přednášky. Nestačí však pouhé nafilmování přednášejícího. Celkový záběr vyučujícího a prezentační plochy se ukázal jako nevhodný. Názornější je využití systémů jako je např́klad MediaSite, který zvlášt' zaznamenává přednes vyučujícího a zvlášt' prezentaci nebo činnost na počitači. Obě složky jsou následně spolu synchronizovány a student si je může přehrávat od libovolného místa. Video je přehlednější, činnost na počítači je dostatečně kvalitně zaznamenána a není potřeba dlouhého a náročného střihu výsledné přednášky.

Pomocí částečně strukturovaného rozhovoru s distančními studenty kurzu Programování v C a kurzu Programování v C++ bylo zjištěno, že 78 \% dotazovaných ocenilo video návody a video přednášky, které jim pomohly lépe pochopit praktická témata. Část studentů by dala přednost kratším video záznamům před dvou hodinovým záznamem prezenčních přednášek.

\section{Závěr}

Výuka programování v distanční formě studia přináší nové problémy. Studenti hlavně v prvních ročnících distanční a kombinované formy studia mají výrazně horší úspěšnost než prezenční studenti. Velmi mnoho studentů se v prvním semestru ani nedostaví ke zkoušce či zápočtu. Je proto potřeba zvýšit kvalitu studia, nabídnout kvalitní učební materiály v elektronické formě a zajistit vhodné ř́zení studia. Ke zkvalitnění značnou mírou přispívá využití hodnocené elektronické konference kurzu a častější aktivita studentů během semestru.

Je-li potřeba studenty v distančním studiu naučit praktickým dovednostem, ukazuje se vhodné připravit video návody a video přednášky a dále vyžadovat po účastnících kurzu řešení dostatečného množství praktických programů.

\section{Literatura}

Bednaříková, I. (2001). Vytvářeni studijnich textů pro distančni vzdělávání, VUP Olomouc.

Englebrecht, J. C., SCORM, J. (2003). Deployment Issues in an Enterprise Distributed Learning Architecture, The Elearning Developers' Journal. 
Fojtík, R. (2006). Problematika didaktických testů v e-learningu. Technológia vzdelávania. 2006, Volume XIV Number 4.

Lanzzilloti, R. \& Ardito, C. (2006). eLSE Methodology: a Systematic Approach to the e-Learning Systems Evaluation. Journal of Educational Technology \& Society. 2006. Volume 9 Number 4.

McPhee, I., Marks, D. \& Duffy, I. (2012). Comparison of equated learning for online and on-campus postgraduate students on academic achievement, The University of the Fraser Valley Research Review. Volume 4: issue 2.

http://www.academia.edu/2362331/COMPARISON_OF_EQUATED_LEARNING_FO R_ONLINE_AND_ON-

CAMPUS_POSTGRADUATE_STUDENTS_ON_ACADEMIC_ACHIEVEMENT. 